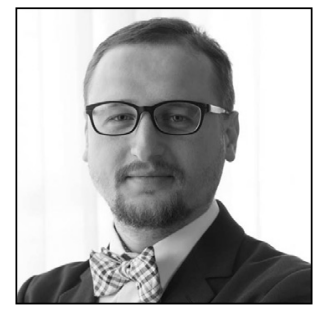

Mykhailo Shumylo

\title{
The Pension System of Ukraine: On Its Way to a Fundamental Reform
}

\section{Introduction}

Since the introduction of the first pension laws, no country has achieved perfection, and if it has reached high efficiency of the pension system, then over time that has still had to be modified in line with economic requirements. The Ukrainian pension system was formed in the era of industrialisation, rapid population growth, and the administrative-planned economy. Although it should be noted that until 1939, in the territory of today's western Ukraine, which was part of the Second Polish Republic, a very effective and, for the inter-war period, progressive pension system was functioning in Europe. The collapse of the Soviet Union and the transition to a market economy, persistent economic and demographic crises, and political instability (through which, among other things, pension reform became a hostage to political speculation and the flowering of social populism) led to the fact that in more than 25 years of independence of Ukraine, an effective pension system that would guarantee decent pensions to the citizens was not created. The research presented here is an attempt to summarise the history and current state of pension reform in contemporary Ukraine, and to point out vital issues that are being resolved and ones that still need to be addressed. An important aspect of understanding the correctness or inappropriateness of the reforms' direction is the conformity of newly valid legal acts to international standards in the social sphere.

\section{The place of Ukraine's pension provision in the globalised world}

Pension provision is one element of the economic system of Ukraine. The rights to pension are among the key social rights defined by the Constitution of Ukraine and the laws of Ukraine, rights that not only are proclaimed or declared but also are implemented in practice and affect each person who is an active participant in public life.

The supreme law of the land declares Ukraine to be a welfare state, and its second section clearly states that citizens have the right to social security, which includes the right to be financially supported in the event of complete, partial, or temporary disability; widowhood; unemployment as a result of circumstances beyond their control; old age; and other circumstances envisaged by law. This right is guaranteed via 
compulsory state social insurance at the expense of insurance contributions effected by citizens, enterprises, institutions, and other organisations, as well as budgetary and other sources of social security; through establishment of a network of state, municipal, and private institutions for taking care of the disabled and others.

Pensions and other social benefits and payments that are the main source of livelihood should ensure a standard of living that is not lower than the subsistence minimum specified by law ${ }^{{ }^{* 1}}$.

Normative consolidation of social rights in Ukrainian legislation is generally in line with European standards (the formal fixing of various rights in the field of pension provision) - namely, the European Social Charter (revised) (1996), signed by Ukraine in $2006^{*}$, and the European Code of Social Security (revised) (1990) ${ }^{*}$, which was signed by Ukraine in 2016. Ukraine has also ratified several conventions of the International Labour Organization: Convention Concerning Minimum Standards of Social Security (No. 102) ${ }^{*}$, ratified in 2006; Convention Concerning Basic Aims and Standards of Social Policy (No. 117) ${ }^{*}$, ratified in 2015; Convention Concerning Equality of Treatment of Nationals and Non-nationals in Social Security (No. 118) ${ }^{*}$; and Convention Concerning Invalidity, Old-Age and Survivors' Benefits (No. 128) ${ }^{*}$. However, as is rightly pointed out by Georg Lohmann and Stefan Gosepath, socio-economic rights are positive, since certain positive measures need to be taken to ensure their provision. In contrast, classical civil rights are negative ones, since others must refrain from certain actions for their implementation ${ }^{*}$. The main problem of the Ukrainian social sphere in general and pension provision in particular is not that one or another right is not fixed but that the realisation of that right may be complicated by dint of the imperfect mechanism of its implementation. In addition, the weakness of the Ukrainian economy, which has a direct impact on social protection, cannot be ignored. There can be no high level of social protection in conditions of permanent economic crisis, a high level of shadow employment, etc. The combination of these factors leads to a low level of pension, which can be raised only under a comprehensive reform of labour; tax; and, of course, pension legislation.

Studying the data from the international ranking Global AgeWatch Index ${ }^{*} 9$ (which covers 96 countries, or $91 \%$ of people who have reached 60 years of age) shows that the world is home to 901 million people who have reached 60 years of age, which is $12.3 \%$ of the world's population; by 2030 , this figure will have increased to $16.5 \%$, or 1,402 million, and by 2050 the number will be 2,092 million, or $21.5 \%$ of the inhabitants of the planet. Today, nearly 150 million people do not get pension benefits. By 2050, in such countries as China, India, and the United States, the number of pensioners in each will have risen to more than 100 million. According to estimates, women who have reached 60 years of age are very likely to live to age 82, and 60-year-old men to 79 years. A positive trend is that between 1990 and 2015 the number of countries that had implemented a pension system increased by $50 \%$.

In this ranking for 2015, Ukraine occupies 73rd position out of 96 countries: it is one of the lowest positions among the countries of the Eastern Europe; the situation is worse only in Moldova (77nd position). Neighbouring and nearby countries hold the following positions: 23 for Estonia, 29 for Georgia, 32 for

1 The Constitution of Ukraine. 28 June 1996. Available at http://zakon2.rada.gov.ua/laws/show/254к/96-вp (most recently accessed on 20.7.2017).

2 The European Social Charter. 1996. Available at http://www.coe.int/en/web/turin-european-social-charter/charter-texts (most recently accessed on 20.7.2017).

3 The European Code of Social Security. 1990. Available at http://www.coe.int/en/web/turin-european-socia-lcharter/treaties1 (most recently accessed on 20.7.2017).

4 Convention Concerning Minimum Standards of Social Security. (1955). Available at http://www.ilo.org/dyn/normlex/en/ f?p=NORMLEXPUB:12100:0::NO::P12100_INSTRUMENT_ID:312247 (most recently accessed on 20.7.2017).

5 Convention Concerning Basic Aims and Standards of Social Policy. (1962). Available at http://www.ilo.org/dyn/normlex/ en/f?p=NORMLEXPUB:12100:0::NO::P12100_ILO_CODE:C117 (most recently accessed on 20.7.2017).

6 Convention Concerning Equality of Treatment of Nationals and Non-nationals in Social Security. 1964. Available at http:// www.ilo.org/dyn/normlex/en/f?p=NORMLEXPUB:12100:0::NO::P12100_ILO_CODE:C118 (most recently accessed on 20.7.2017).

7 Convention Concerning Invalidity, Old-Age and Survivors' Benefits. 1967. Available at http://www.ilo.org/dyn/normlex/ en/f?p=NORMLEXPUB:12100:0::NO::P12100_ILO_CODE:C128 (most recently accessed on 20.7.2017).

8 S. Hosepat, H. Lomann (eds). Філособія прав людини / За редакцї̈ Ш. Госепата та Г. Ломанна; Пер. з нім. О. Юдіна та Л. Доронічевої ['Philosophy of Human Rights, Edited by S. Hosepat and H. Lomann and Translated from the German by O. Yudin and L. Doronicheva']. Kiev: Ніка-Центр 2008 (in Ukrainian), p. 21.

9 The Global AgeWatch Index 2015. Available at http://www.helpage.org/global-agewatch/population-ageing-data/ infographic/ (most recently accessed on 20.4.2017). 
Poland, 35 for Latvia, 39 for Hungary, 40 for Slovakia, 45 for Romania, 63 for Lithuania, 64 for Belarus, and 65 for Russia. The first five positions are occupied by Switzerland, Norway, Sweden, Germany, and Canada, and the bottom positions in the ranking, from 92nd place downward, are held by Pakistan, the West Bank and Gaza (Palestine), Mozambique, Malawi, and Afghanistan.

According to the data of the Pension Fund of Ukraine, as of 1 April 2017 there were over 11,900 million pensioners in Ukraine. ${ }^{*}{ }^{*}$ The average pension in the country is 1,832 UAH (approx. 61 euros) ${ }^{*}{ }^{*}$; ; however, the amount depends on the structure of the economy of a given region. The average salary in Ukraine on 1 May 2017 was 6,840 UAH $^{*}{ }^{12}$ (equivalent to 228 euros). The statistics show that at present the pension corresponds to replacement of $30 \%$ of salary, which is in line with neither ILO Convention 102 nor the European Social Security Code, according to which the proportion of salary to replacement pension shall not be lower than $40 \%$.

In addition to economic factors, it is necessary to take into consideration such important aspect as transformation - as a concept and as part of the essence of the social state.

\section{Changing the paradigm of social protection in the twenty-first century}

In the context of the future development of social rights - their extension in general and social security in particular - it is possible to draw an unambiguous conclusion that Ukraine is influenced by global trends. It is obvious that the twentieth century was a century of consolidation and affirmation of the right to social security. In fact, the basic index of social rights was formed in the last century (it is not exhaustive and will be supplemented in connection with the development of society). Basic social rights not only became enshrined in the constitutions of the countries of the world but became common to the mass consciousness of citizens. In the twentieth century, high standards of social protection were laid down also, standards that Ukraine is still only trying to meet. In the twenty-first century, new challenges are appearing, among which are various major economic crises, globalisation, ageing of populations, unemployment, migration and internally displaced persons, wars, and issues of refugees. The objective of Ukraine in this connection is to maintain its social standards and improve them such that they fulfil the standards of the European Union and International Labour Organization. A global trend that can be observed in Ukraine as well is a movement away from the concept of the paternalistic social state in which the main burden of social protection lies with the state. The associated problem is especially acute in Ukraine. This trend is inevitable. Although the process is proceeding slowly, the state is moving away from paternalism, interpreted as material support of any and all citizens who are in trouble in the form of direct payments from the state budget. Today in Ukraine, the birth of a neopaternalistic state can be observed, in which this social function is performed through wider application and extension of methods of social-policy implementation, based on prevention of social risks.

In addition, future social-security recipients should be aware that the availability and quantity of social benefits depends on their active work and participation in the social-insurance system. At the heart of a new approach to the development of the social state, the principle of personal responsibility of citizens should come above all. Everyone must do his utmost to maintain his standard of living, now and in the future. The incorporation into the labour and social-security legislation of the principle of personal responsibility for financial security in cases of old age and disability will be decisive in the formation of a new paradigm for the state of social welfare. The state under such circumstances is modified, transformed from provider into the guarantor of social protection and a regulator and organiser of the effective functioning of social protection of citizens.

Professor Gaabriel Tavits is among those who speak about the need for new approaches in the sphere of social security. Social-security schemes built upon the principle of mandatory membership do not function well in the new economic conditions. There is need to redefine the social-security protection, in a manner that takes into account the changes in employment relationship. The social-security ideology and

10 See http://www.pfu.gov.ua/pfu/doccatalog/document?id=273640 (most recently accessed on 20.4.2017).

11 Available at http://www.pfu.gov.ua/pfu/doccatalog/document?id=280384 (most recently accessed on 20.7.2017).

12 Available at http://index.minfin.com.ua/index/average/ (most recently accessed on 20.7.2017). 
principles established in the nineteenth century no longer serve very well. The understanding that socialsecurity protection should be applied for employees is valid within a general framework, but in the digital economy is only partly applicable. Social security needs to protect only those people who are willing to get protection and who are interested in such protection. In cases wherein a working person is not interested in social-security protection, that person's protection should not be mandatory. Especially in cases of new forms of employment, there is a need to rethink mandatory social-security protection when the working people themselves are not interested in such protection. It is the right time to reconsider the position and the meaning of social-security protection, in the digital age and in the age of Industry $4.0^{* 13}$.

In our opinion, one of the examples of such development in the social sphere that Ukraine could follow is that of the Kingdom of the Netherlands, which is in the mainstream of social-sphere reform in Europe. The new monarch of this wealthy country, Willem-Alexander, in his first recourse to Parliament in 2013, said: 'The classical welfare state is slowly but surely evolving into a "participation society".' The point is that the public systems should start encouraging self-reliance over government-dependency ${ }^{* 14}$. First of all, this is linked to the fact that modern mechanisms of high-level social protection either are not working well today or will not be able to function effectively in the near future. If the twentieth century focused on social protection by the state of its citizens, such a philosophy can not justify itself in the twenty-first century. Consequently, it is necessary to change the philosophy for social protection. In our opinion, the idea of self-sufficiency of citizens in their old age is decisive today. The state is not a provider of pensions but a pension-provision administrator. Today, every country in Europe is looking for its own recipes to prevent reduction in the level of pensions. The most widespread ingredients in these are increasing of the retirement age, lengthening of the insurance period, maximisation of the introduction of private (accumulative) forms of pension insurance, and the like. Regrettably, nowadays in Ukraine's parliament, society, and science of social-security law, a vision of the problem through the prism of public social security 'from cradle to grave' dominates, by and large. It is obvious that the economic reality is relentless, and if we do not start changing the system of social protection with evolutionary methods rooted in modernity, the market economy will do so with revolutionary methods that must not be allowed in any case, because the risks with such changes are unpredictable.

\section{Stages of pension-system reform in Ukraine}

Pension legislation in Ukraine is described as having undergone three significant changes. These are the reforms of 1991, 2003, and 2011. To these it is now possible to add those of 2015, which was marked by significant legislative changes. It can be said without exaggeration that in that year, Parliament made a breakthrough in reforms to special pension provision. It involved assignment of new special pensions. This marks a significant step towards the establishment of social justice in pension provision. It ultimately entails, above all, the cancellation of special pensions ('VIP pensions') except pensions of military personnel and scientists. However, the author would go further: the author believes that in the future, only pensions for servicemen should remain, as expressly envisaged by Article 17 of the Constitution of Ukraine. In additional changes in 2015, the legislation pertaining to regulation of pensions for the service period was significantly changed. On one hand, the insured period of service required for the awarding of these types of pensions was extended. On the other hand, a retirement age was introduced for the first time in the history for the special pensions. A minimum certain service period was introduced, which, though shorter than the service period for general pensions, still constitutes an additional legal fact without which pension for the service period can not be awarded.

The turning point for the Ukrainian pension system may be 2017, provided that the fifth stage of the reform of pension legislation, its improvement, comes to pass. The main changes would involve the modernisation of the solidarity system for pensions (the first level). Among the main changes proposed by the

13 Gaabriel Tavits. Changing world of labour and social protection. - N.M. Parkhomenko et al. (eds). Ефективність норм права. Зб. наук. пращь. Матеріали VII міжнар. наук.-практ. конф. (Київ, 17 лист. 2016 р.) /за заг. ред. Н.М. Пархоменко, М.М. Шумила, І.О. Ізарової ['Effectiveness of Norms of Law: A Collection of Scientific Works - Materials of the VII International Scientific-Practice Conference (Kiev, 17 Nov. 2016), Edited by N.M. Parkhomenko, M.M. Shumylo, and I.O. Izarova']. Kiev: Ніка-Центр 2016. Available at http://idpnan.org.ua/files/-1-efektivnist-norm-prava.pdf (most recently accessed on 20.7.2017), pp. 426-429.

14 The Dutch rethink the welfare state. Nima Sanandaji, 11.2.2013. Available at http://www.newgeography.com/ content/004028-the-dutch-rethink-welfare-state (most recently accessed on 20.4.2017). 
government ${ }^{* 15}$ is the final cancellation of special pensions for civil servants, prosecutors, local government officials, academics, etc.

Regrettably, the Ukrainian parliament has only today come to consider this issue, while the establishment of uniform pension rules for civil servants and for other citizens in Central and Eastern Europe came about in the '9os. Basic pension laws were adopted then in Latvia (1995), Estonia (1993), Lithuania (1995), Hungary (1991), Slovakia (1992), and Poland (1999).

In addition, the draft law 'On Amendments to Certain Legislative Acts of Ukraine Pertaining to Pension Rises' (registration number 6614), which is extremely important, envisages a gradual increase in the qualifying level of insurance-covered time from 15 to 35 years by 2028 and making establishment of a retirement pension in the first place contingent on it. That is, a person who has reached the age of 60 may receive a retirement pension if he or she has accumulated 35 years of insurance; otherwise, such a person may retire at the age of 63. If, having reached the age of 63, a person still has not completed a 35-year insurance period, the right to a pension may arise when that person reaches the age of 65 . However, if a person who has reached age 65 does not have the required insurance experience (again, 35 years), that person may not have the right to a retirement-age pension and shall receive a monthly social benefit from the state. Through the mechanism of increasing the insurance experience required, the retirement age is raised; doing this is necessary, but the issue is causing a flurry of criticism in Parliament.

One of the controversial proposals made by the government is that during the period of participation in the system of compulsory state pension insurance, the value of one year of insurance be set equal to $1 \%$ instead of the current $1.35 \%$. Such a novel move will necessarily lead to a reduction in the size of the pension of people who enter retirement after the entry of this law into force. The main motivation of the government here lies in the fact that such an innovation would render it possible to raise pensions for those who are already in retirement. Such changes would lead to a further reduction in the rate of replacement of wages by the pension, which is already lower than the $40 \%$ defined as appropriate by international standards. This approach is not supported by international experts or the scientific community.

Ministry of Social Policy of Ukraine does not plan to implement the second level of the reform - the accumulation-based system - in 2017. In our opinion, that state of affairs does not contribute to the stability and effectiveness of pension provision in Ukraine. Hence, one can talk about the inhibition of pension reform, which does not contribute to the establishment of the classical three-level system.

Since 2003, Ukraine has had private pension provision in place (i.e., the third level). Although non-state pension provision is foreseen by the current legislation, it does not operate on national scale and is hostage to the economic crisis. However, even under such conditions, non-state pension insurance remains one of the most progressive legal mechanisms for ensuring and guaranteeing decent security in old age. Its appearance with the adoption of Law of Ukraine 1057, titled 'On Private Pension Provision' (of 9.7.2003), constituted to some extent a revolution in the system of pension provision. Rejection of the mandatory method of legal regulation in the sphere of pension provision granted the latter greater autonomy in the law of social security. Availability of this legal mechanism of pension provision singles out pension legislation, pulling this individual element of social-security law to a qualitatively new level. A private form of pension provision indicates the possibility of functioning of the latter beyond mandatory standards. The basis for the regulation of the system of private pension provision is a contract - in the terminology of the legislation, a pension contract.

However, more than a decade of its existence notwithstanding, it is difficult to assess the private pension system as having experienced broad establishment. Let us consider the situation on 1 January 2017, when the State Register of Financial Institutions (SRFI) contained data ${ }^{* 16}$ on 64 non-state pension funds (NPFs) and 22 administrators (reference figures for comparison: in early 2016, there were 76 NPFs and 23 administrators of NPFs; in 2015, there were 81 and 27, respectively).

According to the information from the SRFI, there are NPFs registered in eight regions of Ukraine, with the largest number of NPFs associated with Kiev: 46 , or $71.9 \%$ of the total number of registered NPFs.

15 Проект закону “Про внесення змін до деяких законодавчих актів України щодо підвищення пенсій” ('Draft for the law “On Amendments to Certain Legislative Acts of Ukraine Pertaining to Pension Rises"), registration number 6614 (in Ukrainian) Available at http://w1.c1.rada.gov.ua/pls/zweb2/webproc4_2?id=\&pf3516=6614\&skl=9 (most recently accessed on 20.7.2017).

16 Available at http://nfp.gov.ua/content/stan-i-rozvitok-npz.html (most recently accessed on 20.4.2017). 
The situation on 31.12.2016 was that administrators of NPFs had concluded 62,600 pension contracts; that is $4.9 \%$ (or 2,900 contracts) more than the 2016 total. The breakdown of pension contracts in 2016 is as follows:

- 55,200 contracts with the depositors being physical entities

- 100 contracts with the depositors being individual entrepreneurs

- 7,300 contracts with the depositors being legal entities

By the reckoning on 31.12.2016, the total number of NPF participants was 834,ooo people (comparative figure representing the situation on 31.12.2015: 836,700 people), of whom 81,300 were receiving pension benefits ( $9.7 \%$ of the total number of participants).

Total income earned from the investment of pension assets amounted to 10,800 UAH (around 37.9 million euros) on 31.12.2016, having increased in comparison to the situation on 31.12.2015 by 208.3 million UAH (7.3 million euros), or $23.9 \%$.

Expenses reimbursed for from the account of pension-fund assets had, on 31.12.2016, increased by $14.2 \%$ from the equivalent figure for 2015 and in general for the period of the pension funds' lifetime amount rose to 245.7 million UAH (6.8 million euros), or $11.5 \%$ of the total value of NPF assets.

\section{The form of pension provision}

The issue of the form of social or pension legislation has been brought up repeatedly both in scientific discussions and at the level of draft laws. Thus, in the early years of communist power, there was a certain 'trend' toward codification, and at precisely this time the first draft Penal Code of the Ukrainian Soviet Socialist Republic on social security was developed (1929) ${ }^{* 17}$, yet this project has never been completed there was no discussion of the Pension Code at that time. Since the declaration of Ukraine's independence, discussions of codification in the social sphere have undergone certain reformulation, with some scholars having returned to the idea of codification of all social protection and adoption of the Social Code, among them N. Bolotina ${ }^{* 18}$, S. Synchuk ${ }^{* 19}$, S. Prylypko ${ }^{* 20}$, O. Moskalenko ${ }^{* 21}$, and others. Others are supporters of the idea of codification of pension legislation in the form of a new Pension Code: O. Tyshchenko ${ }^{{ }^{22} \text {, }}$ Y. Simutina ${ }^{* 23}$, I. Gumeniuk ${ }^{* 24}$, L. Knyazkova ${ }^{* 25}$, etc. I belong to the second group of scientists. Parliament

17 I.B. Usenko (И.Б. Усенко). Первая Кодификация законодательства Украинской ССР: монография ['First Codification of Legislation of the Ukrainian SSR: A Monograph']. Kiev: Scientific Thought 1989, pp. 96-99) (in Russian).

18 N.B. Bolotina (Н.Б. Болотіна). Законодавство Украӥни в сфері соціального захисту населення та перспективи його розвитку // Соціальне законодавство України: теоретичні та практичні проблеми розвитку: матер. науковоі конференції (Київ, 23 березня 2005 р.) ['Legislation of Ukraine in the Sphere of Social Protection of the Population and the Perspectives on Its Development / Social Legislation of Ukraine: Theoretical and Practical Problems of Development Material from a Scientific Conference (Kiev, 23 March 2005)']. Харків 2007, p. 16 (in Ukrainian).

19 S.M. Synchuk (С.M. Синчук). Правовідносини соціального забезпечення: суб’єти, зміст, об'єкти: монографія ['Legal Relations of Social Provision: Subjects, Content, Objects: A Monograph']. Lviv, Ukraine: ЛНУ імені Івана Франка 2015 (in Ukrainian), pp. 352-353.

20 S.M. Prylypko (С.М. Прилипко). Проблеми теорї права соціального забезпечення: монограбія ['Problems of the Theory of Social Provision: A Monograph']. Kharkiv, Ukraine: Берека Нова 2006 (in Ukrainian), pp. 240-241.

21 O.V. Moskalenko (О.В. Москаленко). Основні засади зазальнообо'язкового державного соціального страхування в умовах ринкової економіки ['The Basic Principles of General Compulsory State Social Insurance in the Conditions of a Market Economy']. Kharkiv, Ukraine: Юрайт (in Ukrainian), pp. 318-328, 352-353.

22 O.V. Tyschenko (О.В. Тищенко). Право соціального забезпечення Украӥни: теоретичні та практичні проблеми формування і розвитку галузі: монографія ['The Law on Social Provision of Ukraine: Theoretical and Practical Problems of Formation and Development of the Area: A Monograph']. Kiev: Прінт-Сервіс 2014 (in Ukrainian), pp. 123-126, 390-393.

23 N.M. Khutorian (H.M. Хуторян) et al. Правові проблеми пенсійного забезпечення в Украӥні / Н.М. Хуторян, М.М. Шумило, М.П. Стадник та ін.: монографія ['Legal Problems of Pension Provision in Ukraine, by N.M. Khutorian, M.M. Shumylo, M.P. Stadnyk, and Others: A Monograph']. Kiev: Iн Юpe 2012 (in Ukrainian), pp. 106-123.

24 I.O. Gumeniuk (І.О Гуменюк). Особливості кодифікації пенсійного законодавства ['Peculiarities of pension legislation's codification']. - Наукові записки Інституту законодавства при Верховній Раді України ['Scientific Notes of the Institute of Legislation of the Verkhovna Rada of Ukraine'] 2014/5) (in Ukrainian), p. 70-73.

25 L.M. Kniazkova (Л.M. Князькова). Деякі питання систематизації пенсійного законодавства Украӥни / Проблеми кодифікацї̈ трудового законодавства України: тези доповідей учасників наукової конференції (Київ, 26 квітня 2017 p.). ['Some Issues of Systematisation of Pension Legislation of Ukraine - Problems of Codification of Labour Legislation in Ukraine: Theses of Reports of Participants in a Scientific Conference (Kiev, 26 April 2017)']. Kiev: Прінт Сервіс 2017 (in Ukrainian), pp. 241-244. 
has responded to such tendencies in the theory of social-security law; therefore, three projects related to the Social Code of Ukraine were undertaken (numbers $6170(2005)^{*_{2} 6}, 11061(2012)^{*_{2} 7}$, and $2311(2013)^{*_{2} 8}$; at the same time, there have been two projects focused on the Pension Code: No. 5460/p (2000) ${ }^{* 29}$ and No. $4290 a(2014)^{*} 30$. All of these projects were rejected; while there were various reasons for this, the main issue was that their developers were individual MPs or groups thereof, rather than the Ministry of Social Policy of Ukraine or the Pension Fund of Ukraine - this led to a low standard of the draft codes. Today, the government has initiated and is implementing a pension reform that on 13.7.2017 was supported in the first reading by Parliament ${ }^{*} 31$; in author's opinion, this is a good reason to raise the issue of codification of pension legislation again.

As was mentioned above, Ukraine's pension legislation has undergone significant reform four times, but there are several reservations pertaining to the form as well as the content of such novelties. One of the main shortcomings of the previous pension reforms was the failure to select a correct form of its implementation. In our view, pension-provision reform should be carried out with the involvement of a wide range of experts in law, economics, demographics, etc., including legal scholars, economists / economics practitioners, and representatives of civil society. It is necessary to work out the concept to be used for reforms to Ukrainian pension legislation; the need for its systematisation is obvious. The outcome of the pension reform should be a Pension Code of Ukraine that takes into account the provisions of the current legislation and consolidates the novel elements that will improve pension provision for citizens. It can be noted that the pension legislation has turned into a confusing cobweb of legal norms that is incomprehensible to the average citizen. Regrettably, the proliferation of pension legislation has brought harm to the pension system of Ukraine. With a burgeoning body of normative legal acts, the efficiency of legal regulation does not increase, and in some cases it declines. All these factors together led to misuse of legislative norms, and, hence, a significant proportion of the administrative is made up of disputes about awarding, payment, and recalculation of pensions. The only way out of this situation may be adoption of a Pension Code of Ukraine - a single, consolidated normative legal act that unites all three levels of the Ukrainian pension system; addresses special pension provision; and addresses the issues of payment of the individual social contributions and of awarding, payment, and recalculation of pensions. During the codification, it will be necessary to complete the pension reform in Ukraine, since the so-called reforms of 1991, 2003, 2011, and 2015 cannot be considered to be fully accomplished. They only partially reformed some aspects of pension provision; despite being stages of a single, perennial pension reform that lasted more than 20 years. Now, the Pension Code of Ukraine could crown this, completing the effort.

Summing up the issue of the form of pension legislation, we can conclude that there is an objective need for the elaboration and adoption of the Pension Code, but there is no political will. The long-term negative practice of carrying out successive stages of pension reform by means of laws on amendments to other laws is being continued.

26 Проект Соціального кодексу України № 6170 (Draft of the Social Code of Ukraine, No. 6170) (in Ukrainian). Available at http://w1.c1.rada.gov.ua/pls/zweb2/webproc2_5_1_J?ses=88\&num_s=2\&num=6170\&date1=\&date2=\&name_ $\mathrm{zp}=\&$ out $\_$type $=\& \mathrm{id}=($ most recently accessed on 20.7.2017).

27 Проект Соціального кодексу України № 11061 (Draft of the Social Code of Ukraine, No. 11061) (in Ukrainian). Available at http://search.ligazakon.ua/__doc2.nsf/link1/JF8J900A.html (most recently accessed on 20.7.2017).

28 Проект Соціального кодексу України № 2311 (Draft of the Social Code of Ukraine, No. 2311) (in Ukrainian). Available at http://search.ligazakon.ua/1_doc2.nsf/link1/JG1S700A.html (most recently accessed on 20.7.2017).

29 Проект Пенсійного кодексу України № 5460/п (Draft of the Pension Code of Ukraine, No. 5460/p) (in Ukrainian). Available at http://w1.c1.rada.gov.ua/pls/zweb2/webproc4_1?pf3511=8797 (most recently accessed on 20.7.2017).

30 Проект Пенсійного кодексу України № 4290a (Draft of the Pension Code of Ukraine, No. 4290a) (in Ukrainian). Available at http://w1.c1.rada.gov.ua/pls/zweb2/webproc4_1?pf3511=51712 (most recently accessed on 20.7.2017).

31 Проект закону “Про внесення змін до деяких законодавчих актів України щодо підвищення пенсій” (Draft of the law 'On Amendments to Some Legislative Acts of Ukraine Pertaining to Pension Rises') (see Note 15). 


\section{The decisions of the Constitutional Court of Ukraine in the field of pension provision}

The most important problem facing the modern pension system is, without exaggeration, the application of pension legislature by courts. In this context, it is possible to discern three main components: the application of pension legislation within the constitutional and administrative judiciary and by the European Court of Human Rights (ECHR).

An important role in ensuring compliance with the Constitution in general and its provisions for social rights in particular is played by the Constitutional Court of Ukraine (CCU), which is the sole body of constitutional jurisdiction in Ukraine. The task of the CCU is to guarantee the supremacy of the Constitution of Ukraine as supreme law of the state all over Ukraine. That is, the CCU is a body that does not allow narrowing of the content and scope of existing rights and freedoms in the course of adoption of new laws or of amendment to current legislation, including the resolutions of the Cabinet of Ministers of Ukraine. In all, in its activity since 18 October 1996, the CCU has adopted 18 resolutions that are related in one way or another to the right to social protection. These resolutions can be classified on the basis of the subject of the dispute: those dealing with the constitutionality of some provisions of the law of Ukraine on budget ( 6 adjudications), dealing with social protection of special categories of citizens (civil servants, police officers, prosecutors, military personnel, etc.) (5 adjudications), addressing social protection of judges (4 adjudications), on issues of workplace accidents and occupational illnesses (2 adjudications), and dealing with other matters (one case each to do with temporary disability, court jurisdiction for social lawsuits, and payment of pensions to persons permanently residing abroad).

The Court's resolutions on the constitutionality of provisions of paragraph 2 of Part 1 of Article 49 and the second sentence of Article 51 of the law of Ukraine titled 'On Mandatory State Pension Insurance', of 7.10.2009 (No. 25-op/2009), are absolutely fair. The Constitutional petition raised the question of unconstitutionality of certain provisions of said law related to cancellation of payment of pensions to pensioners throughout the time of their permanent residence abroad if Ukraine has not concluded an international agreement on pension provision with the respective state and if consent for the ratification of such an international treaty was not granted by the Verkhovna Rada of Ukraine.

In that case, the Court stated that by the disputed provisions of the law, the Constitutional right to social protection was made contingent on the fact of Ukraine concluding an international agreement on pension provision with the respective state. Thus, the state, contrary to the Constitution's guarantees of social protection for all persons who are eligible for old-age pension, at the legislative level deprived pensioners of this right in cases wherein they have chosen for permanent residence a country with which a relevant agreement has not been concluded. In light of the legal, social nature of pensions, a citizen's right to receive the awarded pension shall not be connected with such conditions as permanent residence in Ukraine; the state, in accordance with its Constitution's principles, is obliged to guarantee this right irrespective of where the person who was awarded pension lives - in Ukraine or abroad.

On the above-mentioned grounds, the provisions of the law related to cancellation of payment of pensions to pensioners during the time of their permanent residence (or stay) abroad in cases wherein Ukraine has not concluded an international agreement with the respective state were found to contradict the requirements of the Constitution of Ukraine on the strengthening and protection of human rights and freedoms, inadmissibility of restrictions to Constitutional rights and freedoms, equality of Constitutional rights between citizens without regard for their place of residence, guaranteeing of care and protection to those citizens of Ukraine who are living or staying abroad, and the right to social protection in old age. Therefore, the CCU recognised the legal provisions in question as being inconsistent with the Constitution of Ukraine and violating the Constitutional right to social protection. This resolution has not found its implementation in the law yet and is not yet honoured by the Pension Fund of Ukraine, although this position of the CCU was indicated in paragraph 2 of the informational letter of the Supreme Administrative Court of Ukraine of 18.2.2014 (No. 212/11/14-14), which provides that from 7 October 2009 the payment of pensions to citizens who go abroad for permanent residence is regulated by the norms of the law On Mandatory State Pension Insurance in account of the CCU's resolution of 7 October 2009 (25-op/2009). 


\section{The European Court of Human Rights on the protection of pension rights}

The importance of the practice of the ECHR has been repeatedly emphasised by representatives of legal science, as well as by judges, human-rights activists, and lawyers.

Professor P.M. Rabinovitch notes that the Court's rather extensive (nearly forty-years') and non-substantive practice of protecting rights demonstrates the fairness of its decisions. This can be traced mainly in two directions: 1) adjustment by the respondent state to the national legislation for reason of the relevant decisions of the Court and 2) compensation for losses incurred by the victim (applicant). In addition, this legal scientist emphasises that the decision of the Court is evidence of the validity of the interpretation of the phenomenon of human rights as a social one, 'earthly' (and not biological, psychophysiological, cosmic, 'divine', etc.). The Court's activity convincingly demonstrates the universality of those general regularities of social cognition that are most fully and clearly formulated by the dialectical epistemology of social determinism. These regularities have come to triumph in the law-justifying, law-making, law-enforcement activity of such a venerable international body as the Court (which features, as we know, qualified professional lawyers from all member states of the Council of Europe) $)^{*}{ }^{32}$.

S.V. Shevchuk, who is currently a judge with the Constitutional Court of Ukraine and in 2009-2012 was a judge of the European Court of Human Rights, notes that the acts of the Court have normative indications and that its practice is a recognised source of law in Ukraine. The legal scientist continues by stating that the ECHR in Ukraine should be applied in a comprehensive way as a set of rules of law together with sound practice in their application ${ }^{*} 33$.

The positive impact of the Court's judgements is obvious and indisputable for improvement and Europeanisation of the Ukrainian legal system. No decent modern-day research in the field of law omits analysis of the practice of the ECHR. The law on social security in general and scientific studies of pension law in particular are no exception. As of 2016, researchers of pension-provision problems and reforms to the pension system of Ukraine have analysed the ECHR resolution from the case Pichkur $v$. Ukraine ${ }^{*} 34$ principally, on application 10441/o6, which came into force on 7.2.2014. The essence of the grievance was that people who go abroad for permanent residence are denied the right to receive pension. The above-mentioned decision of the ECHR was unprecedented for legal practice in the protection of the right to pension. For the first time, a pension-related case against Ukraine was heard, and a resolution was handed down in favour of the applicant. An interesting feature of this resolution is that the ECHR took into account and analysed in detail the resolution of the CCU. With the ECHR decision taken into account, the position of the national body for Constitutional control is an indication that not only the CCU refers to the legal position of the ECHR; this is a mutual process in cases related to Ukraine. A result of hearing of this case was support for the resolution of the CCU and commitments by Ukraine to pay out Mr Pichkur's pension.

The ECHR turned its attention to pension provision again and issued a resolution in the Petrychenko. $v$. Ukraine case ${ }^{*} 35$ on 12 July 2016, on application 2586/07. In this case, which was brought on 12 December 2006, the court recognised infringement of paragraph 1 of Article 6 of the European Convention for the Protection of Human Rights and Fundamental Freedoms due to the fact that in this case the judges of domestic courts had not considered the applicant's arguments with direct reference to Article 46 of the Constitution of Ukraine that the amount of his pension was lower than that set at the appropriate time as a minimum for subsistence. In consequence, the ECHR ruled that Ukraine was to pay the applicant, within three months, 1,200 euros' compensation for moral damage and an additional amount equal to any tax that might be charged.

32 Р.М. Rabinovitch (П. М. Рабінович). Рішення Європейського суду з прав людини: до характеристики концептуальнометодологічних засад їх обгрунтування // Практика Європейсъкого суду з прав людини. Рішення. Коментарі ['Resolutions of the European Court of Human Rights: On the Characteristics of the Conceptual and Methodological Foundations of Their Justification / The Practice of the European Court of Human Rights - Decision, Comments'], 1999/1, pp. 358-365 (in Ukrainian).

33 S.V. Shevchuk (С.В. Шевчук). Загальнотеоретичні проблеми нормативності актів судової влади: автореф. дис.... д-ра юрид. наук ['General Theoretical Problems of Normative Acts of the Judiciary: Author's Abstract']. A Dissertation by Doctor of Law S.V. Shevchuk'] (in Ukrainian). Kharkiv, 2008, p. 25.

34 Case of Pichkur v. Ukraine, No. 10441/06. Materials available at http://hudoc.echr.coe.int/app/conversion/ pdf/?library=ECHR\&id=001-127810\&filename=001-127810.pdf (most recently accessed on 20.7.2017).

35 Case of Petrychenko v. Ukraine, No. 2586/07. Materials available at http://zakon2.rada.gov.ua/laws/show/974_b58 (most recently accessed on 20.7.2017). 
Firstly, analysis of the ECHR resolution clearly demonstrates that it is of a formal rather than substantive character. That is, the Court pointed out the violation of the form of hearing - namely, that the applicant had complained under paragraph 1 of Article 6 of the convention that the domestic courts had not considered his arguments that the amount of his pension had been calculated in contradiction to the provisions of the Constitution.

Thus, the ECHR did not consider the merits of the case and confined itself simply to the arguments of Mr Petrychenko not having been taken into account by the national courts. This resolution is universal and can be applied to any category of cases if at any stage of court hearing arguments or evidence is not taken into account, especially if the arguments or evidence is envisaged by the laws of the land. Furthermore, the ECHR thereby gave attention to this problem for a second time, since an identical resolution related to Ukraine, also in the sphere of pension provision, had been issued in 2006, in the case Pronina $v$. Ukraine ${ }^{*} 36$, on application 63566/oo.

By its nature, the ECHR resolution does not assess the size of pensions in Ukraine. Moreover, it does not recognise low pensions to constitute a violation of an individual's rights. In addition, the applicants' claims had been rejected when the pension-insurance system was newly introduced, and deviation from elementary principles of pension provision had just begun. Nowadays, there are no pensions paid in the solidarity system that are below subsistence-minimum level, and one can state therefore that the ECHR resolution is relevant only in a retrospective sense and related to specific applicants. However, it raises the other important issue, that the courts ignore direct orders - in this case, found in Constitutional guarantees.

The resolutions of the European Court of Human Rights in the social sphere are extremely important for Ukraine: 1) they are a source of law and must be honoured; 2) for avoidance of further appeals by citizens of Ukraine to the ECHR, the legislation that violates the Convention should be amended; 3) ECHR resolutions have become an integral part of the implementation of justice in Ukraine - they are referred to and their legal position is used in the arguments in litigation - and 4) the ECHR resolution is a subject of scientific analysis that promotes a deeper understanding of human rights. In general, an ECHR resolution is a guideline for the further consolidation and protection of human rights in general and social rights in particular.

\section{Conclusions}

In summary, the overall conclusion that pension provision in Ukraine is far from perfect both in form and in content can be drawn. However, it should be recognised also that there are no ideal pension systems. Each country in its own way is trying to ensure decent pension in terms of its own demographic, economic, political, and social conditions, and Ukraine is no exception in this regard. Ukraine is, in this context, in a much more difficult situation than other Eastern European countries, as 74 years in the Soviet Union have had a negative impact on all spheres of public life. Only today, with the advent of a new generation - a changing of the guard in public policy - are major reforms in various spheres, including social ones, starting. The reforms that are currently under way or planned are far from perfect, but most important, the author believes, is that the process of changes in the sphere of pension provision is in progress. It has not stalled.

Certainly, Ukraine's experience today cannot be interesting for most countries of Western and Eastern Europe, since they are in the mainstream of social reforms and, in fact, often in a position to give guidance for reforming Ukraine, but the Ukrainian experience and Ukrainian mistakes on the path to reform may be of interest for post-Soviet countries (with the exceptions of Estonia, Latvia, and Lithuania) that, have undergone serious economic and moral deformations caused by the Soviet authorities, which have not yet been fully overcome, along with those countries that are moving towards the achievement of European standards for quality of life after retirement.

36 Case of Pronina v. Ukraine, No. 63566/00. Materials available at http://freecases.eu/Doc/CourtAct/4524971 (most recently accessed on 20.7.2017). 